2. Як свідчить багаторічний досвід, отриманий при епідрозслідуванні спалахів сальмонельозу на території області, запобігання виникненню масової інфекційної захворюваності можливе за рахунок дотримання вимог чинного законодавства на кожному окремому етапі технологічного процесу: від сировини - до готової продукції.

3. Недосконалість нормативної бази стосовно забезпечення якості та безпечності харчових продуктів та нехтування відповідальністю на етапі поступлення сировини, виготовлення продукції, зберігання, транспортування та реалізації - загрожують неблагоприємними наслідками для здоров'я людини.

\section{EPIDEMIOLOGYCAL RESULTS OF SALMONELLOSIS OUTBREAKS IN TERNOPIL REGION}

V.O. Panychev, N.V. Tsyapa, M.M. Pavelyeva, I.V. Kulachkovska, S.V. Matsipura, N.I. Hodovana, O.Ya. Bilynska, Yu.H. Dementiev, T.B. Barna, S.Ye. Yasinovska

SUMMARY. The outbreak of salmonellosis depend on the efficiency of operations professionals towards establishing a common factor of transmission and the existence of a cell - from the quality of the anti-epidemic measures.

Key words: outbreak, salmonella, Salmonella enteritidis, epidemiology products.

Отримано 2.03.2015 р.

(c) Колектив авторів, 2015

УДК 616.24-002.5-036.13-085.2/3

\author{
М.М. Кужко, Л.М. Процик, Н.М. Гульчук, О.В. Аврамчук, Л.І. Гречаник
}

\title{
ЕФЕКТИВНІСТЬ ЗАСТОСУВАННЯ МОКСИФЛОКСАЦИНУ В ІНТЕНСИВНУ ФАЗУ ПРОТИТУБЕРКУЛЬОЗНОЇ ХІМІОТЕРАПЇ̈ У ХВОРИХ НА ВПЕРШЕ ДІАГНОСТОВАНИЙ ТУБЕРКУЛЬОЗ ЛЕГЕНЬ
}

\author{
Національний інститут фртизіатрії і пульмонології ім. Ф.Г. Яновського НАМН України, \\ Головний військовий клінічний госпіталь, м. Київ
}

Мета дослідження - встановити ефрективність моксифрлоксацину в інтенсивну фразу протитуберкульозної хіміотерапії у хворих на вперше діагностований туберкульоз легень (ВДТЛ). У дослідження було включено 102 хворих: 31 отримували моксифлоксацин 0,4 г замість етамбутолу, 27-моксифлоксацин 0,4 г замість ізоніазиду, 44 - стандартну протитуберкульозну терапію протягом 2 місяців. Встановлено, що застосування моксифлоксацину замість етамбутолу в інтенсивну фразу хіміотерапії призводить до підвищення частоти припинення кашлю на 23,4 \%, мокротиння на 27,9 \% через 2 тижні лікування, підвищення частоти припинення бактеріовиділення на 26,5 \% за 1-й міс. лікування, скороченню термінів припинення бактеріовиділення до $(4,6 \pm 0,4)$ тиж. порівняно із стандартною протитуберкульозною хіміотерапією.
Ключові слова: вперше діагностований туберкульоз легень, лікування, моксифрлоксацин.

Туберкульоз залишається розповсюдженим захворюванням, що важко піддається лікуванню, інвалідизує хворих, завдає відчутний соціально-економічний збиток [1]. Більше 50 років, із часу введення в режим лікування рифрампіцину, не було запроваджено нових антимікобактерійних препаратів. За даний час тільки фрторхінолони показали багатообіцяючу активність щодо мікобактерії туберкульозу (МБТ) [2]. Gillespie S.H. та Billington O. протестували in vitro активність 5 фрторхінолонів (моксифрлоксацину, левофрлоксацину, ципрофрлоксацину, офрлоксацину, спарфлоксацину) та ізоніазиду з метою оцінки їх потенційної активності стосовно МБТ та деяких інших нетуберкульозних мікобактерій. Моксифллоксацин виявився найактивнішим 3 хінолонів, пере- 


\section{ОРИГІНАЛЬНІ ДОСЛІДЖЕННЯ}

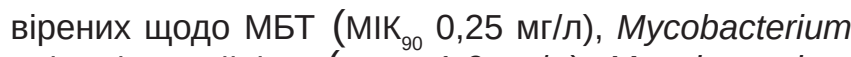
avium-intracellulare ( $\mathrm{MIK}_{90} 1,0 \mathrm{Mг/л),} \mathrm{Mycobacterium}$ kansasii $\left(\mathrm{MIK}_{90}\right.$ 0,06 мг/л) i Mycobacterium fortuitum $\left(\mathrm{MIK}_{90}\right.$ 1,0 мг/л), що вказало на його перспективність як антимікобактерійного засобу [3]. Моксиорлоксацин має сприятливу фрармакокінетику, великий об'єм розподілу, може проникати в епітеліальні клітини і макрофраги [4].

Активність моксифлоксацину in vitro проти МБТ було підтверджено в експериментальних дослідженнях на мишах [5] та у клінічних дослідженнях при монотерапії [6], що підвищило ймовірність того, що препарат може бути використаний у режимах хіміотерапії туберкульозу. Наступні дослідження на мишах показали, що комбінації протитуберкульозних препаратів, які включали моксифллоксацин, мали значно більшу бактерицидну активність, ніж стандартні режими лікування [7]. На сьогодні доведено ефективність фрторхінолонів у лікуванні хворих на хіміорезистентний туберкульоз, а моксифлоксацин, зокрема, рекомендований до застосування у всіх режимах хіміотерапії для даної категорії хворих, у тому числі і при розширеній резистентності МБТ [8].

Проте дотепер не існує спільної думки дослідників щодо можливості та доцільності застосування моксифрлоксацину в режимах хіміотерапії пацієнтів на ВДТБ, не визначено терміни та дози застосування препарату.

Метою даного дослідження було встановити ефективність і переносимість моксифлоксацину в інтенсивну фразу (ІФ) протитуберкульозної хіміотерапії у хворих на ВДТБ.

\section{Матеріали і методи}

У дослідження було включено 102 хворих на ВДТБ. Основну групу становили 58 пацієнтів, які отримували моксифрлоксацин в ІФ протитуберкульозної терапії, контрольну - 44 хворих, які отримували стандартну специфічну терапію, згідно з чинними Наказами МОЗ України. 3 метою визначення найбільш ефективного режиму хіміотерапії, пацієнти основної групи були розподілені на дві підгрупи: пацієнти IA (31 особа) отримували моксифлоксацин 0,4 г per os щодня замість етамбутолу, пацієнти ІБ (27 осіб) отримували моксифлоксацин 0,4 г per os щодня замість ізоніазиду в інтенсивній фразі хіміотерапії. В усіх групах переважали пацієнти чоловічої статті - 20 (64,5 \%), 19 (70,4 \%), 28 (63,6 \%) відповідно ( $>>0,05)$, що характерно для захворюваності на туберкульоз легень в нашій країні. Хворі у досліджуваних групах також були ідентичні за віком, однаково переважали особи до 40 років, найбільш працездатного віку: 15 (48,4 \%) пацієнтів у ІА групі, 16 (59,2 \%) -у ІБ та 23 (52,3 \%) - у II групі, p>0,05.
Серед клінічних фрорм туберкульозу інфрільтративна фрорма зустрічалася найчастіше -у 23 (74,2 \%), 21 (77,8 \%), 34 (77,3 \%) хворих відповідних груп, р>0,05. Деструктивні зміни у легенях до початку лікування відмічались у всіх пацієнтів. У третини хворих у легенях діагностували одну каверну до 4 см - у 12 (38,7 \%), 9 (33,3 \%), 14 (31,8 \%) випадках, p>0,05. У другої третини пацієнтів було декілька порожнин розпаду у легенях, але їх розмір не перевищував 4 см: 11 (35,5 \%) - у ІА групі, 11 (40,7\%) - у ІБ та 14 (31,8 \%) - у II, p>0,05. Бактеріовиділення виявляли методом засіву та мазка у більшості хворих у кожній із груп: IA група - у 29 (93,5 \%), ІІ - у 26 (96,3 \%), II - у 40 (90,9\%) випадках ( $>0,05)$. При виявленні резистентності (полі- та мультирезистентності), за даними ТМЧ, пацієнти із даного дослідження виключалися.

\section{Результати досліджень та їх обговорення}

Клінічні прояви туберкульозу легень перед початком проведення ІФ антимікобактерійної терапії були зафіксовані у більшості пацієнтів, які входили у дослідження. Зокрема, на кашель скаржилися 29 (93,5 \%) пацієнтів ІА групи, 26 (96,3 \%) - ІБ та 40 (90,1%) - II групи. Так, вже через 2 тижні у більшості пацієнтів, у режими протитуберкульозної терапії яких був включений моксифлоксацин, не відмічали кашлю - 22 (75,9 \%) у IA та 23 (88,5 \%) - у ІБ групах. 3 пацієнтів, які отримували стандартну специфічну терапію, припинення кашлю було лише у 26 (65,1 \%) випадків, p<0,05.

Виділення мокротиння було у 26 (83,9 \%) пацієнтів IA , 21 (77,8 \%) - ІБ та 32 (80,0 \%) - II груп. Динаміка припинення (зменшення) виділення мокротиння була схожою із динамікою припинення кашлю, що обумовлено подвійною дією моксифлоксацину - на МБТ та неспецифрічну бактерійну фрлору. Пацієнти, які отримували моксифлоксацин в ІФ, вже через два тижні відмічали зменшення або повне припинення мокротиння у 24 (93,5 \%) та 18 (85,7 \%) випадків у ІА та ІБ групах відповідно, що на 27,9 і 20,1 \% більше, ніж у хворих, які отримували стандартну хіміотерапію ( $\left.\mathrm{p}_{\mathrm{IA- \|}}<0,05, \mathrm{p}_{\mathrm{IE}-\|}>0,05\right)$.

Задишку при фрізичному навантаженні відмічали більшість пацієнтів у всіх групах: 22 (71,0 \%) - у IA, 20 (70,4 \%) - у ІБ, 31 (70,5 \%) - у ІІ групі відповідно. Зменшення задишки при фрізичному навантаженні за 2 тижні перебування у стаціонарі відмічали лише половина пацієнтів - 12 (54,5 \%), 9 (45,0 \%), 14 (45,2 \%) відповідно в усіх групах, p>0,05. Незначна позитивна клінічна динаміка продовжувала відмічатися і в наступний місяць: зменшення задишки у хворих IA групи - у 17 (77,3 \%), ІБ - у 16 (80,0 \%), II - у 23 (74,2 \%) випадках ( $>0,05)$. Збереження задишки у великої кількості пацієнтів обумовлено великим поширеним специфічним процесом із масивним ураженням паренхіми легень. 


\section{ОРИГІНАЛЬНІ ДОСЛІДЖЕННЯ}

Як свідчить табл. 1, у переважної більшості пацієнтів, які отримували моксиорлоксацин в ІФ, пік припинення бактеріовиділення припадає на 4-6-й тиждень лікування. Найбільш ефективним за даний період часу виявився режим хіміотерапії, в якому замість етамбутолу використовували моксиолоксацин (IА група). Так, вже через 4 тижні хіміотерапії МБТ у мокротинні не виявля- ли у 20 (69,0 \%) хворих IA групи, що вірогідно більше, ніж у контрольній групі - у $17(42,5 \%)$ осіб $\left(p_{\text {ІА-ІІ }}<0,05\right)$. Заміна ізоніазиду на моксиорлоксацин у стандартному режимі хіміотерапії (ІБ група) не призвело до вірогідного збільшення припинення бактеріовиділення - у 15 $(57,7 \%)$ пацієнтів порівняно із стандартним режимом терапії - у $17(42,5 \%)$ хворих ( ІБ-ІІ $>0,05)$.

Таблиця 1

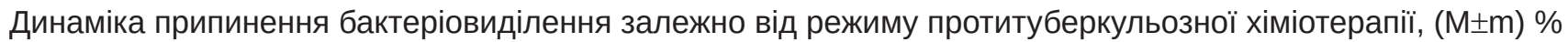

\begin{tabular}{|c|c|c|c|c|c|c|}
\hline \multirow{3}{*}{ Термін лікування } & \multicolumn{6}{|c|}{ Групи хворих } \\
\hline & \multicolumn{2}{|c|}{ IA } & \multicolumn{2}{|c|}{ ID } & \multicolumn{2}{|r|}{ II } \\
\hline & Абс. & $\mathrm{M} \pm \mathrm{m}$ & Абс. & $\mathrm{M} \pm \mathrm{m}$ & Абс. & $\mathrm{M} \pm \mathrm{m}$ \\
\hline Через 2 тижні & 6 & $20,7 \pm 7,5$ & 6 & $23,1 \pm 8,3$ & 5 & $12,5 \pm 5,2$ \\
\hline Через 4 тижні & 20 & $69,0 \pm 8,6^{*}$ & 15 & $57,7 \pm 9,7$ & 17 & $42,5 \pm 7,8$ \\
\hline Через 6 тижнів & 26 & $89,6 \pm 5,7$ & 21 & $80,8 \pm 7,7$ & 29 & $72,5 \pm 7,1$ \\
\hline Через 8 тижнів & 28 & $96,6 \pm 3,4$ & 24 & $92,3 \pm 5,2$ & 34 & $85,0 \pm 5,6$ \\
\hline Через 12 тижнів & 29 & 100,0 & 26 & 100,0 & 37 & $92,5 \pm 4,1$ \\
\hline
\end{tabular}

Примітка. * - значення показника між IA і II групами вірогідно відрізняється, p<0,05.

Після 2 місяців лікування була оцінена рентгенологічна динаміка процесу у пацієнтів основної і контрольної груп. Після завершення ІФ лікування у частини пацієнтів відмічали повне розсмоктування та ущільнення вогнищево-інфільтративних змін у легенях. Застосування моксифлоксацину не призвело до швидшого зникнення патологічних змін у легенях - у 25 (80,6 \%) хворих IA, у $21(77,8 \%)$ - ІБ і у 32 (72,7 \%) - II групи відповідно $\left(p_{\text {IA-II }}>0,05, p_{\text {IE- II }}>0,05\right)$.

Одним із головних критеріїв оцінки режиму протитуберкульозної терапії є загоєння порожнин деструкції у легенях. 3 появою нових фрторхінолонів, зокрема моксифлоксацину, у якого виявилася потужна бак- терицидна і стерилізаційна активність щодо МБТ, сприятлива фрармакокінетика та хороші профрілі безпеки, припускали, що він може виявитися корисним у скороченні тривалості лікування туберкульозу, при використанні разом з іншими бактерицидними препаратами першого ряду.

Замінивши у стандартному режимі терапії етамбутол на моксифлоксацин, препарат із високою бактерицидною активністю, очікували і на більш високу інтенсивність регресії порожнин розпаду у легенях. Результати застосування моксифрлоксацину у режимах ІФ терапії на інтенсивність регресії каверн представлено у табл. 2.

Вплив моксифрлоксацину на інтенсивність регресії порожнин розпаду по закінченні ІФ

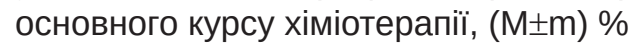

\begin{tabular}{|l|c|c|c|c|c|c|}
\hline \multirow{2}{*}{$\begin{array}{c}\text { Стан деструктивних } \\
\text { змін }\end{array}$} & \multicolumn{5}{|c|}{ Групи хворих } \\
\cline { 2 - 7 }
\end{tabular}

Примітка. Міжгрупові значення показника вірогідно не відрізняються, p>0,05.

Виходячи 3 даних табл. 2, застосування моксифрлоксацину замість етамбутолу в ІФ протитуберкульозної терапії призвело до загоєння порожнин розпаду у 5 $(16,1 \%)$ хворих, що лише на 7,0 \% більше, ніж при застосуванні стандартної хіміотерапії, $\mathrm{p}_{|\mathrm{A}-| \mid}>0,05$. Загалом, позитивна динаміка відмічалася у хворих всіх груп, вірогідного впливу моксисрлоксацину не відмічали - 27 (87,1 \%) осіб у IА, $20(74,1 \pm 8,4) \%$ - у ІБ, $29(65,9 \pm 7,1) \%-$ - II групі, $p_{|A-| \mid}>0,05, p_{\text {|Б-|| }}>0,05$.
Негативна динаміка після завершення ІФ була пов'язана із низькою прихильністю до лікування та поганою переносимістю протитуберкульозних препаратів.

Приведені дані по частоті зникнення клінічних симптомів (припинення кашлю, мокротиння, задишки) та частоті припинення бактеріовиділення та загоєння порожнин розпаду показали неоднозначні результати по ефрективності моксифлоксацину. 3 метою визначення 
спроможності моксифрлоксацину скоротити основний курс хіміотерапії, проаналізовані терміни зникнення клінічної та рентгенологічної симптоматики у пацієнтів різних груп залежно від режиму протитуберкульозної хіміотерапії.

Як свідчить табл. 3, застосування моксифрлоксацину в ІФ хіміотерапії замість етамбутолу та ізоніазиду в стандартних режимах призводить до вірогідного скорочення термінів зникнення клінічної симптоматики: припинення кашлю - $(1,7 \pm 0,1)$ і $(1,6 \pm 0,1)$ тиж. порівняно із стандартним режимом протитуберкульозної терапії - $(2,2 \pm 0,2)$ і
$(2,1 \pm 0,2)$ тиж. $\left(p_{|A-1|}<0,05, p_{15-1 \mid}<0,05\right)$. Моксифллоксацин належить до IV покоління фрторхінолонів («респіраторні фрторхінолони»), які характеризуються високою активністю у відношенні як до грам(+) і грам(-) аеробів, так і до внутрішньоклітинних збудників і анаеробів. Висока активність проти перерахованих збудників і хороший фрармакокінетичний профріль моксифллоксацину дозволяє швидко зменшити кашель із виділенням харкотиння порівняно з ізоніазидом та етамбутолом, які не впливають на інші інфекції дихальних шляхів.

Таблиця 3

Терміни зникнення клінічної симптоматики у пацієнтів різних груп залежно від режиму

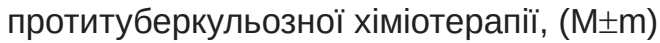

\begin{tabular}{|c|c|c|c|c|c|c|}
\hline \multirow{3}{*}{ Показник } & \multicolumn{3}{|c|}{ Групи хворих } & \multirow{3}{*}{$\mathrm{p}$ IA-IE } & \multirow{3}{*}{$p|A-I|$} & \multirow{3}{*}{ p IE-II } \\
\hline & IA & IS & II & & & \\
\hline & $(\mathrm{M} \pm \mathrm{m})$ & $(\mathrm{M} \pm \mathrm{m})$ & $(\mathrm{M} \pm \mathrm{m})$ & & & \\
\hline Кашель (тиж.) & $1,7 \pm 0,1$ & $1,6 \pm 0,1$ & $2,2 \pm 0,2$ & $p>0,05$ & $p<0,05$ & $\mathrm{p}<0,05$ \\
\hline Мокротиння (тиж.) & $1,7 \pm 0,1$ & $1,6 \pm 0,1$ & $2,1 \pm 0,1$ & $p>0,05$ & $\mathrm{p}<0,05$ & $p<0,05$ \\
\hline Задишка (тиж.) & $2,4 \pm 0,3$ & $2,3 \pm 0,3$ & $2,3 \pm 0,2$ & $p>0,05$ & $p>0,05$ & $p>0,05$ \\
\hline Припинення бактеріовиділення (тиж.) & $4,5 \pm 0,4$ & $5,0 \pm 0,4$ & $5,9 \pm 0,4$ & $p>0,05$ & $p<0,05$ & $p>0,05$ \\
\hline $\begin{array}{l}\text { Розсмоктування вогнищево- } \\
\text { інфрільтративних змін (міс.) }\end{array}$ & $4,2 \pm 0,2$ & $4,4 \pm 0,3$ & $4,8 \pm 0,3$ & $p>0,05$ & $p>0,05$ & $p>0,05$ \\
\hline Загоєння деструкцій (міс.) & $4,1 \pm 0,2$ & $4,2 \pm 0,3$ & $4,7 \pm 0,3$ & $p>0,05$ & $p>0,05$ & $p>0,05$ \\
\hline Тривалість стаціонарного лікування (міс.) & $2,2 \pm 0,2$ & $2,3 \pm 0,2$ & $2,5 \pm 0,2$ & $p>0,05$ & $p>0,05$ & $p>0,05$ \\
\hline
\end{tabular}

Замінивши у стандартному режимі специфрічної терапії етамбутол на моксифлоксацин, отримали режим, у якому всі препарати володіють бактерицидною активністю стосовно МБТ. Аналіз ефективності даного режиму у пацієнтів IA групи показав, що очікуване вірогідне скорочення термінів отримали припинення бактеріовиділення $(4,6 \pm 0,4)$ тиж. порівняно із стандартною терапією $(5,9 \pm 0,4)$ тиж. $\left(p_{\mid A-\|}<0,05\right)$. Заміна ізоніазиду на моксифрлоксацин не призвела до скорочення термінів припинення бактеріовиділення - $(5,0 \pm 0,4)$ і $(5,9 \pm 0,4)$ тиж. $\left(p_{15-11}>0,05\right)$.

Застосування моксифлоксацину в інтенсивну фразу терапії не призвело до покращення репаративних процесів у легенях - терміни розсмоктування патологічних змін - $(4,2 \pm 0,2)$ міс. та загоєння порожнин деструкції $(4,1 \pm 0,2)$ міс. вірогідно не відрізнялися від стандартної терапії - $(4,8 \pm 0,3)$ і $(4,7 \pm 0,3)$ міс. відповідно, $\mathrm{p}_{\text {ІА-л| }}>0,05$, $\mathrm{p}_{\mathrm{IБ}-1 \mid}>0,05$.

Не дивлячись на вірогідно швидші терміни припинення бактеріовиділення із застосуванням моксисрлоксацину, по завершенні ІФ терапії частота припинення мікобактеріовиділення була однаково високою у всіх пацієнтів: у 96,6 \% - IA, у 92,3 \% - ІБ та у 85,0 \% хворих II групи (p>0,05), тому і тривалість стаціонарного лікування також не відрізнялася $(2,2 \pm 0,2)$ міс. у IA групі, $(2,3 \pm 0,2)$ міс. - у IБ, $(2,5 \pm 0,2)$ міс. у II групі, $p_{|A-\||}>0,05, p_{15--1 \mid}>0,05$. Тобто, моксисрлоксацин може бути призначений замість ізоніазиду в ІФ при його непереносимості. Необхідні подальші дослідження з призначенням моксифрлоксацину на весь основний курс хіміотерапії у вперше діагностованих хворих на туберкульоз з перспективою заміни ізоніазиду при його резистентності.

\section{Висновки}

1. Застосування моксифрлоксацину замість етамбутолу в ІФ протитуберкульозної хіміотерапії у хворих на ВДТБ призводить до:

- підвищення частоти припинення кашлю на 23,4 \%, мокротиння на 27,9 \% через 2 тижні лікування порівняно із стандартним режимом хіміотерапії $(p<0,05)$;

- підвищення частоти припинення бактеріовиділення на 26,5 \% за 1-й міс. лікування ( $<<0,05)$, порівняно із стандартною схемою лікування;

- загоєння або регресії порожнин розпаду у легенях у 87,1 \% пацієнтів після завершення ІФ специфрічної хіміотерапії;

- скорочення термінів припинення бактеріовиділення на $(1,5 \pm 0,4)$ тиж. порівняно із стандартною схемою лікування $(p<0,05)$.

2. Застосування моксифлоксацину в ІФ терапії не призводить до підвищення частоти та скорочення тер- 
мінів розсмоктування вогнищево-інфрільтративних змін та загоєння порожнин деструкцій у легенях.

Перспективи подальших досліджень - визначення ефрективності моксифрлоксацину замість етамбутолу в короткострокових 4-хмісячних режимах протитуберкульозної хіміотерапії.

\section{Література}

1. Наукові підходи до вирішення проблем туберкульозу / [Ю.І. Фещенко та ін.] // Укр. пульмонол. журн. - 2013. - № 2. C. 5-14.

2. Ginsberg A.M. Tuberculosis drug development: progress, challenges, and the road ahead / A.M. Ginsberg // Tuberculosis. 2010. - Vol. 90. - P. 162-167.

3. Gillespie S.H. Activity of moxifloxacin against mycobacteria / S.H. Gillespie, O. Billington // J. Antimicrob. Chemother. - 1999. Vol. 44, N 3. - P. 393-395.

4. Comparative pharmacokinetics of ciprofloxacin, gatifloxacin, grepafloxacin, levofloxacin, trovafloxacin, and moxifloxacin after single oral administration in healthy volunteers / [A. Lubasch et al.] // Antimicrob. Agents Chemother. - 2000. - Vol. 44. - P. 2600-2603.

5. Moxifloxacin (BAY12-8039), a new 8-methoxyquinolone, is active in a mouse model of tuberculosis / [E. Miyazaki et al.] // Antimicrob. Agents Chemother. - 1999. - Vol. 43. - P. 85-89.

6. The bactericidal activity of moxifloxacin in patients with pulmonary tuberculosis / [R.D. Gosling et al.] // Am. J. Respir. Crit. Care Med. - 2003. -Vol. 168. - P. 1342-1345.

7. Moxifloxacin-containing regimen greatly reduces time to culture conversion in murine tuberculosis / [E.L. Nuermberger et al.] // Am. J. Respir. Crit. Care Med. -2004. - Vol. 169. - P. 421-426.

8. WHO guidelines for the programmatic management of drugresistant tuberculosis: 2011 update / [D. Falzon et al.] // Eur. Respir. J. - 2011. - Vol. 38. - P. 516-528.

\section{EFFICIENCY OF APPLICATION MOXIFLOXACIN IN THE INTENSIVE PHASE OF ANTITUBERCULOSIS CHEMOTHERAPY IN PATIENTS WITH NEWLY DIAGNOSED PULMONARY TUBERCULOSIS}

M.M. Kuzhko, L.M. Protsyk, N.M. Hulchuk, O.V. Avramchuk, L.I. Hrechanyk

SUMMARY. The aim - to determine the efficacy of moxifloxacin in the intensive phase of antituberculosis chemotherapy in patients with newly diagnosed pulmonary tuberculosis. The study included 102 patients: 31 received moxifloxacin $0,4 \mathrm{~g}$ instead of ethambutol, 27 received moxifloxacin 0,4 $\mathrm{g}$ instead of isoniazid, 44 standard antituberculosis therapy during the 2 months. Established that the use of moxifloxacin instead of ethambutol in the intensive phase of chemotherapy leads to an increase frequency cessation of cough by $23,4 \%$, sputum by $27,9 \%$ after 2 weeks of treatment, increased frequency of of bacteriological conversion by $26,5 \%$ for the 1 st month treatment, reduction of terms of bacteriological conversion up $(4,6 \pm 0,4)$ weeks compared to standard antituberculosis chemotherapy. Key words: newly diagnosed pulmonary tuberculosis, treatment, moxifloxacin.

Отримано 29.02.2015 p.

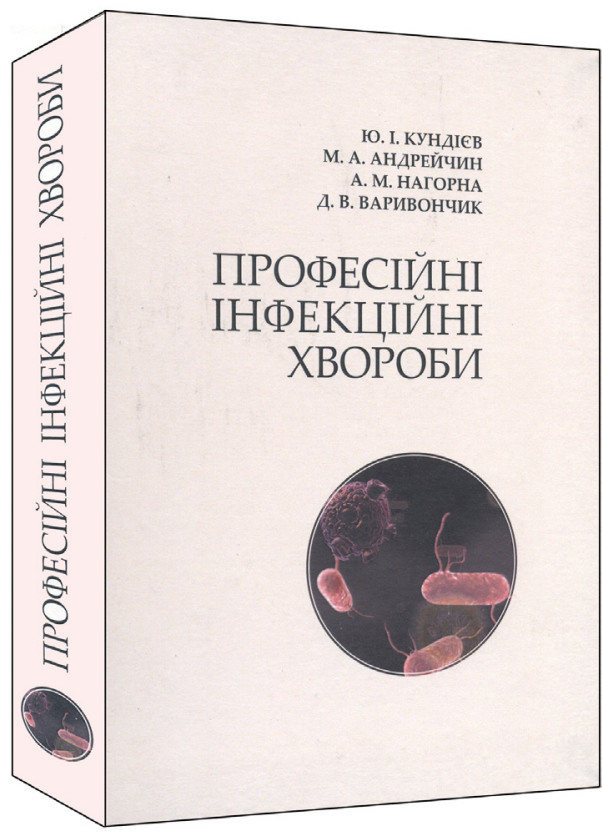

\section{СВІТ ПОБАЧИЛА НОВА КНИГА!}

Профресійні інфекційні хвороби / Ю. І. Кундієв, М. А. Андрейчин, А. М. Нагорна, Д. В. Варивончик. - К. : ВД «Авіцена», 2014. - 528 с.

Висвітлено етіологію, епідеміологію, клінічні прояви, професійні чинники поширення низки інфекційних хвороб, пов'язаних з виробничим середовищем, і відповідні профрілактичні та протиепідемічні заходи. Окремі розділи присвячені проблемам ВІЛ-інфекції/СНІДу, туберкульозу, вірусних гепатитів, зоонозних інсрекцій (бруцельоз, геморагічна гарячка з нирковим синдромом, еризипелоїд, кліщовий енцефаліт, ку-гарячка, Лайм-бореліоз, лептоспіроз, лістеріоз, орнітоз, сибірка, туляремія, ящур).

Для науковців і практикуючих лікарів-гігієністів, епідеміологів, іноекціоністів, лікарів загальної практики і сімейної медицини, які цікавляться професійними захворюваннями. Книга може бути корисною для викладачів профільних кафедр медичних університетів і слухачів фракультетів післядипломної освіти.

3 питань придбання звертатися у ТОВ «Видавничий дім «Авіцена», 03150, Київ-150, а/с 302, тел. +38 044 289-64-49, +38 050 469-58-61. Вартість 305 грн. 